F. XU* , J. KIM, J. WALDMAN, T. WANG, P. DEVINE (MERCK \& CO., INC., RAHWAY, USA) Synthesis of Grazoprevir, a Potent NS3/4a Protease Inhibitor for the Treatment of Hepatitis C Virus Org. Lett. 2018, 20, 7261-7265.

\title{
Synthesis of Grazoprevir
}
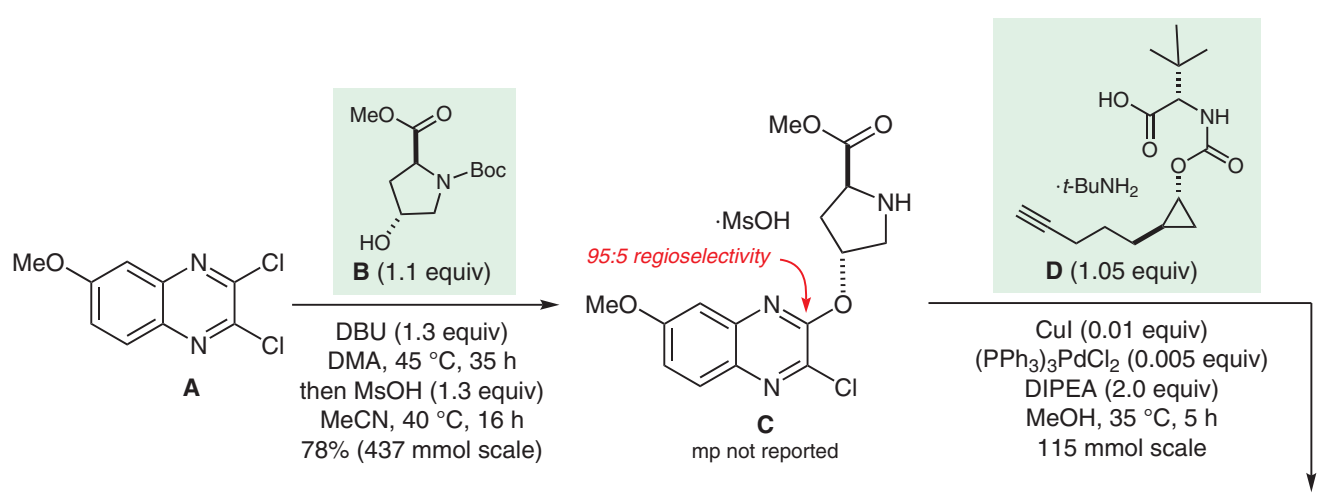<smiles>COC(=O)C1C[C@@H](Oc2nc3cc(OC)ccc3nc2C#CCCCC2CC2)CN1C(=O)C(NC(=O)OC1CC1)C(C)(C)C</smiles>

$\mathrm{mp}$ not reported

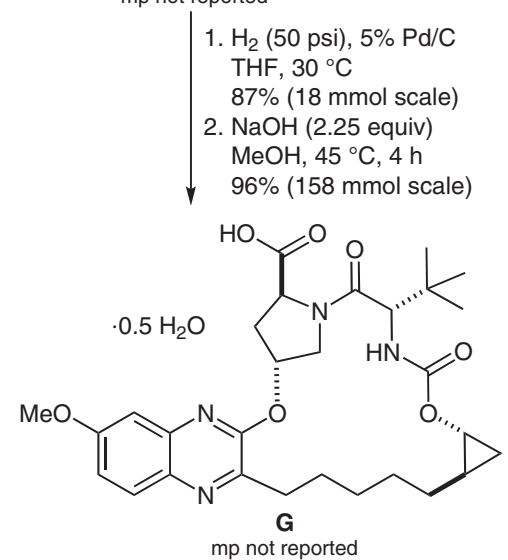

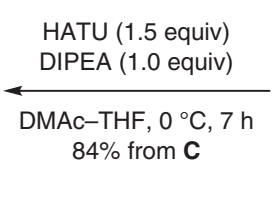
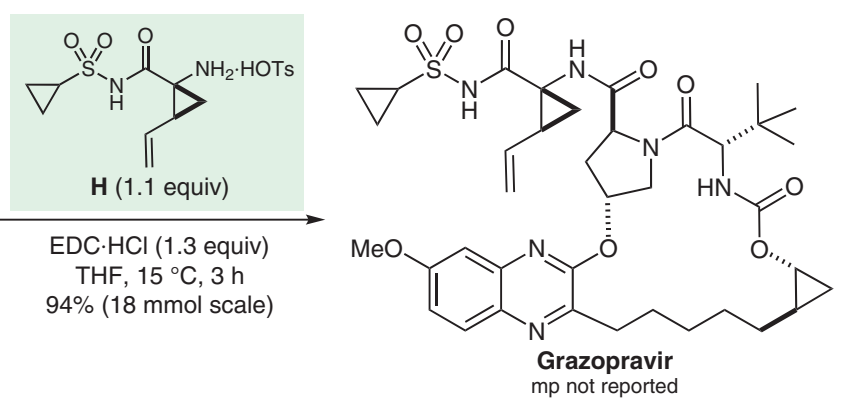

Category

Synthesis of Natural

Products and

Potential Drugs

\section{Key words}

grazoprevir

NS3/4a protease inhibitor

macrolactamization

Sonogashira reaction
Significance: Grazoprevir is an NS3/4a protease inhibitor. It was approved by the FDA in 2016 as a combination drug with elbasvir (Zepatier $\left.{ }^{\circledR}\right)$ for the treatment of hepatitis $C$ viral infections. The scheme depicts the chemistry developed to conjoin the fragments A, B, D, and $\mathbf{H}$ on large scale $(>100 \mathrm{~kg})$ in $51 \%$ overall yield and $>99.8 \%$ purity.
Comment: The thermal instability of the free base of alkyne D was a challenge in the Sonogashira reaction. By using methanol as solvent, catalyst stability and reactivity was improved as evinced by increased catalytic turnover at milder temperatures $\left(35^{\circ} \mathrm{C}\right)$. The free base of sulfonamide $\mathbf{H}$ was unstable at ambient temperature. Therefore, the EDC coupling was conducted at $0{ }^{\circ} \mathrm{C}$ by adding pyridine to a slurry of the acid $\mathbf{G}$ and the PTSA salt $\mathbf{H}$ in THF. 